\title{
FAKTOR-FAKTOR KEPUASAN PENGGUNA TERHADAP KUALITAS PELAYANAN DI TERMINAL MENGWI BADUNG
}

\author{
Zanuar Septyadi $^{1 \S}$, I Gusti Ayu Made Srinadi ${ }^{2}$, Ketut Jayanegara ${ }^{3}$ \\ ${ }^{1}$ Program Studi Matematika, Fakultas MIPA - Universitas Udayana [Email: septyadizanuar@gmail.com] \\ ${ }^{2}$ Program Studi Matematika, Fakultas Mipa - Universitas Udayana [Email: srinadi@unud.ac.id] \\ ${ }^{3}$ Program Studi Matematika, Fakultas Mipa - Universitas Udayana [Email: ktjayanegara@unud.ac.id] \\ ${ }^{\S}$ Corresponding Author
}

\begin{abstract}
Customer satisfaction is the level of customer feeling towards the evaluation of perceived discrepancies between performance or perceived results compared to expectations. Quality is the level of excellence expected to meet customer desires which is a dynamic condition related to products, services, people, processes and the environment that meets or exceeds expectations. Factor analysis is a multivariate analysis method based on correlations between variables. This study discusses the factors of customer satisfaction with service quality in the Mengwi Badung Station. The factors of user satisfaction with the quality of service at the Mengwi Badung Station are caring, physical condition, guarantee, reliability, and responsibility factors.
\end{abstract}

Keywords: Factor Analysis, Satisfaction Customer, Quality Service

\section{PENDAHULUAN}

Bali merupakan salah satu provinsi di Indonesia yang menjadikan industri pariwisata sebagai sektor unggulan dalam menyokong perekonomian masyarakat. Hal ini cukup beralasan karena Bali memiliki keindahan alam yang mempesona dan keanekaragaman budaya yang unik, sehingga menjadi daya tarik tersendiri bagi wisatawan. Menurut Dinas Pariwisata (Disparda) Provinsi Bali (2017) perkembangan pariwisata di Bali selalu mengalami peningkatan selama sepuluh tahun terakhir dan menjadi penyumbang kedatangan wisatawan terbesar ke Indonesia. Pada tahun 2018 kedatangan wisatawan asing ke Bali mencapai 6,070,473 orang sedangkan wisatawan nusantara yang berjumlah 9,757,991 orang (BPS Provinsi Bali, 2019).

Sarana prasarana juga menjadi salah satu hal penting dalam industri pariwisata. Kualitas sarana prasarana yang menunjang seperti penginapan, restoran, tourist information, serta akses awal kedatangan wisatawan harus selalu diperhatikan. Jalur darat merupakan salah satu akses yang banyak digunakan para wisatawan untuk datang ke Bali selain jalur udara. Pada tahun 2015 tercatat 59,6 \% wisatawan nusantara lebih memilih jalur darat untuk berwisata ke Bali (Disparda Bali, 2016). Hal ini yang menyebabkan terminal menjadi salah satu prasarana transportasi yang penting selain bandar udara (Bandara). Salah satu terminal yang menjadi prasarana transportasi vital di Bali adalah Terminal Mengwi.

Terminal Mengwi merupakan terminal penumpang bertipe A yang secara administrasi terletak di Kabupaten Badung. Terminal Mengwi memiliki peranan untuk melayani penumpang umum angkutan antar kota dalam propinsi (AKAP) dan angkutan lintas batas antar negara, angkutan antar kota dalam propinasi (AKDP), angkutan kota (AK) serta angkutan pedesaan (ADES) (Dishubkominfo Badung, 2018). Pentingnya peran Terminal Mengwi sebagai prasarana transportasi sudah tentu menuntut adanya pembangunan infrastuktur yang memadai serta manajemen yang baik untuk dapat meningkatkan kualitas pelayanan terhadap penumpang sehingga penumpang dapat merasa nyaman dan puas.

Penelitian terdahulu tentang kepuasan pengguna terhadap kualitas pelayanan di terminal yang dilakukan oleh Saputra (2010) menghasilkan atribut pelayanan yang paling berpengaruh di Terminal Makassar Metro yang menjadi prioritas utama untuk ditingkatkan 
kinerjanya antara lain waktu menunggu kedatangan dan keberangkatan angkutan umum, sistem informasi pelayanan, penertiban buruh bagasi dan calo, kondisi jalan, ruang tunggu, bengkel, ruang istirahat kru angkutan umum, tempat cuci angkutan umum, toilet dan penerangan dimalam hari.

Hal inilah yang menjadi daya tarik tersendiri bagi peneliti untuk dapat mengukur dan mengetahui tingkat kepuasan pengguna Terminal Mengwi. Tingkat kepuasan pengguna menjadi salah satu faktor keberhasilan pemerintah dalam membangun sarana prasarana yang menunjang pariwisata, mengingat Bali merupakan tujuan utama pariwisata di Indonesia. Model Servqual adalah suatu metode yang digunakan untuk mengukur tingkat kepuasan pengguna terhadap kualitas pelayanan. Model ini mendefinisikan atribut pengukuran kualitas pelayanan jasa yang mewakili 5 dimensi, yaitu Tangible, Reliability, Responsiveness, Assurance, dan Empathy (Parasuraman et al, 1988). Selain pendekatan model servqual, suatu metode kuatitatif juga diperlukan untuk dapat mengukur dan mengetahui tingkat kepuasan pengguna di Terminal Mengwi, salah satunya menggunakan metode analisis faktor.

Analisis faktor merupakan metode analisis multivariat yang didasarkan pada korelasi antar variabel. Analisis faktor termasuk salah satu metode yang dapat digunakan untuk memberikan deskripsi yang relatif sederhana melalui reduksi jumlah variabel yang disebut faktor. Analisis faktor dipergunakan untuk mereduksi data atau meringkas, dari variabel lama yang banyak menjadi sedikit variabel baru yang disebut faktor, dan masih memuat sebagian besar informasi yang terkandung dalam variabel asli (Supranto, 2004).

\section{KAJIAN PUSTAKA}

\subsection{Terminal}

Terminal merupakan prasarana transportasi jalan untuk keperluan menurunkan penumpang dan menaikkan penumpang. Berdasarkan PP RI No 43 tahun 1993 tipe terminal yaitu:

a. Terminal penumpang tipe A, yaitu berfungsi melayani penumpang umum untuk angkutan antar kota dalam propinsi (AKAP), dan angkutan lintas batas antar negara, angkutan antar kota dalam propinasi (AKDP), angkutan kota (AK) serta angkutan pedesaan (ADES).

b. Terminal penumpang tipe B, yaitu berfungsi melayani kendaraan penumpang umum untuk angkutan antar kota dalam propinasi (AKDP), angkutan kota (AK) serta angkutan pedesaan (ADES).

c. Terminal penumpangan tipe $\mathrm{C}$, yaitu berfungsi melayani kendaraan penumpangan umum untuk angkutan pedesaan (ADES).

\subsection{Kepuasan Pelanggan}

Kepuasan adalah tingkat perasaan seseorang setelah membandingkan kinerja atau hasil yang dia rasakan dibandingkan dengan harapannya (Kotler, 2000) Sedangkan menurut (Lupiyoadi, 2006) kepuasan atau ketidakpuasan pelanggan adalah respon pelanggan terhadap evaluasi ketidaksesuaian (disconfirmation) yang dirasakan antara harapan sebelumnya dan kinerja aktual produk yang dirasakan setelah pemakaiannya.

\subsection{Kualitas Pelayanan}

Kualitas merupakan suatu kondisi dinamis yang berhubungan dengan produk, jasa, manusia, proses dan lingkungan yang memenuhi atau melebihi harapan (Yamit, 2005). Pendekatan yang digunakan bahwa kualitas bukan hanya menekankan pada aspek akhir yaitu produk dan jasa tetapi juga menyangkut kualitas manusia, kualitas proses dan kualitas lingkungan. Sangatlah mustahil menghasilkan produk dan jasa yang berkualitas tanpa melalui manusia dan produk yang berkualitas.

\subsection{Dimensi Kepuasan}

Tjiptono (2006) mengutarakan ada lima dimensi service quality. Lima dimensi penilaian kepuasan yaitu, kepuasan kehandalan (reliability), kepuasan responsif (responsiveness), kepuasan keyakinan (assurance), kepuasan empati (emphaty), kepuasan berwujud (tangible).

\subsection{Model Analisis Faktor}

Menurut (Giri, 2004), misalkan terdapat $p$ indikator dan $m$ faktor, maka dapat dibentuk model sebagai berikut: 


$$
\begin{gathered}
X_{1}=\lambda_{11} F_{1}+\lambda_{12} F_{2}+\lambda_{13} F_{3}+\cdots+\lambda_{1 m} F_{m}+\varepsilon_{1} \\
X_{2}=\lambda_{21} F_{1}+\lambda_{22} F_{2}+\lambda_{23} F_{3}+\cdots+\lambda_{2 m} F_{m}+\varepsilon_{2} \\
\vdots \\
X_{p}=\lambda_{p 1} F_{1}+\lambda_{p 2} F_{2}+\lambda_{p 3} F_{3}+\cdots+\lambda_{p m} F_{m}+\varepsilon_{p}
\end{gathered}
$$

dengan:

$$
\begin{array}{ll}
X_{1}, X_{2}, \ldots, X_{p} & =\text { indikator dari } m \text { faktor } \\
\lambda_{i j} & =\text { bobot dari indikator ke- } i \\
& \text { pada faktor ke- } j \\
& i=1,2, \ldots, p \text { dan } j=1,2, \ldots, m \\
F_{1}, F_{2}, \ldots, F_{m} & =\text { faktor ke- } 1 \text { sampai ke- } m \\
\varepsilon_{1}, \varepsilon_{2}, \ldots, \varepsilon_{p} & =\text { galat untuk variabel ke-1 } \\
& \text { sampai ke- } p
\end{array}
$$

Bentuk persamaan (2.1) dapat dituliskan dengan:

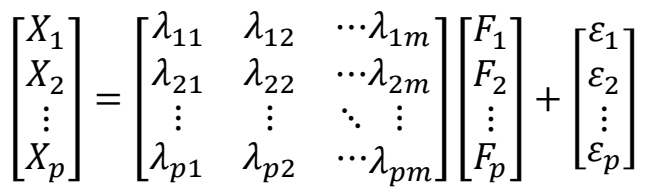

$$
\begin{aligned}
& \text { atau }
\end{aligned}
$$

dengan:

$X_{p \times l}=$ vektor peubah berukuran $(p \times l)$,

$$
X^{\prime}
$$

$F_{m \times l}=$ vektor berukuran $(m \times l)$ dari faktor yang tidak dapat diamati yakni

$F=\left(F_{1}, F_{2}, \ldots, F_{m}\right)$

$\varepsilon_{p \times l} \quad=$ galat dalam vektor berukuran $(p \times l)$ dari galat yaitu $\varepsilon^{\prime}=\left(\varepsilon_{1}, \varepsilon_{2}, \ldots, \varepsilon_{p}\right)$

$\Lambda_{p \times m}=$ matriks pembobot berukuran $(p \times m)$ yaitu:

$$
\Lambda=\left[\begin{array}{cccc}
\lambda_{11} & \lambda_{12} & \cdots & \lambda_{1 m} \\
\lambda_{21} & \lambda_{22} & \cdots & \lambda_{2 m} \\
\vdots & \vdots & \ddots & \vdots \\
\lambda_{p 1} & \lambda_{p 2} & \cdots & \lambda_{p m}
\end{array}\right]
$$

\section{METODE PENELITIAN}

Penelitian ini dilakukan di terminal Mengwi Kabupaten Badung. Waktu penelitian dilakukan pada bulan Juli 2019. Populasi dalam penelitian ini adalah pengguna jasa di Terminal Mengwi Kabupaten Badung. Sampel dalam penelitian ini adalah calon penumpang di area kawasan Terminal Mengwi. Sampel diambil sebanyak 120. Data pada penelitian ini adalah data primer. Sumber data dalam penelitian ini menggunakan metode survey, yaitu dengan cara menyebarkan langsung kuesioner kepada responden. Kuesioner disusun menggunakan skala interval, yaitu skala yang digunakan untuk mengukur pendapat atau persepsi seseorang terhadap suatu fenomena atau gejala sosial dengan cara mengukur panjang garis mulai dari ujung kiri dengan nilai (Sangat Tidak Puas) hingga ujung kanan dengan nilai (Sangat Puas).

Pengambilan sampel pada penelitian ini menggunakan teknik purposive sampling. Dengan teknik ini, sampel yang dipilih telah ditentukan oleh peniliti dengan menetapkan ciri-ciri khusus sesuai dengan tujuan penelitian. Variabel indikator yang digunakan pada penelitian ini, mengacu pada penelitian terdahulu yang dilakukan oleh Taufiq (2010), yaitu:

Tabel 1. Variabel Indikator

\begin{tabular}{|l|}
\hline \multicolumn{1}{|c|}{ Variabel Indikator } \\
\hline Area terminal yang luas $\left(X_{1}\right)$ \\
\hline Tersedia Loket penjualan karcis $\left(X_{2}\right)$ \\
\hline Ruang tunggu penumpang nyaman $\left(X_{3}\right)$ \\
\hline Kamar kecil, toilet, MCK tersedia dan bersih $\left(X_{4}\right)$ \\
\hline Tersedia tempat ibadah $\left(X_{5}\right)$ \\
\hline Tersedia tempat penitipan barang $\left(X_{6}\right)$ \\
\hline Tersedia kios, warung atau kantin $\left(X_{7}\right)$ \\
\hline Penerangan terminal dimalam hari $\left(X_{8}\right)$ \\
\hline $\begin{array}{l}\text { Waktu menunggu antar kedatangan dan } \\
\text { keberangkatan angkutan umum }\left(X_{9}\right)\end{array}$ \\
\hline $\begin{array}{l}\text { Jadwal kedatangan dan keberangkatan angkutan } \\
\text { umum tepat waktu }\left(X_{10}\right)\end{array}$ \\
\hline Tidak ada pemungutan liar seperti calo $\left(X_{11}\right)$ \\
\hline Kebersihan terminal $\left(X_{12}\right)$ \\
\hline $\begin{array}{l}\text { Tersedia layanan informasi mengenai tarif angkutan } \\
\text { umum }\left(X_{13}\right)\end{array}$ \\
\hline Tersedia Rambu dan papan informasi $\left(X_{14}\right)$ \\
\hline Penindakan tegas petugas bagi yang melanggar $\left(X_{15}\right)$ \\
\hline $\begin{array}{l}\text { Tersedia informasi tentang pelayanan angkutan } \\
\text { umum }\left(X_{16}\right)\end{array}$ \\
\hline Pemungutan retribusi penumpang di terminal $\left(X_{17}\right)$ \\
\hline Waktu operasional angkutan umum 24 jam $\left(X_{18}\right)$ \\
\hline $\begin{array}{l}\text { Keramahan petugas terminal dalam melayani } \\
\text { penumpang }\left(X_{19}\right)\end{array}$ \\
\hline $\begin{array}{l}\text { Kemampuan petugas terminal mengatur lalulintas } \\
\text { angkutan umum }\left(X_{20}\right)\end{array}$ \\
\hline Jaminan keamanan dan keselematan $\left(X_{21}\right)$ \\
\hline Ketegasan petugas terminal dalam penertiban $\left(X_{22}\right)$ \\
\hline Perhatian petugas terhadap keluhan $\left(X_{23}\right)$ \\
\hline $\begin{array}{l}\text { Keramahan dan kesopanan petugas terhadap } \\
\text { penumpang }\left(X_{24}\right)\end{array}$ \\
\hline $\begin{array}{l}\text { Tersedia fasilitas pengaduan apabila ada keluhan } \\
\left(X_{25}\right)\end{array}$ \\
\hline Tersedia pelayanan kesehatan bagi penumpang $\left(X_{26}\right)$ \\
\hline
\end{tabular}


Penelitian ini bertujuan untuk mengetahui faktor-faktor yang memengaruhi kepuasan pengguna terhadap kualitas pelayanan di Terminal Mengwi. Adapun langkah-langkah yang dilakukan dalam menganalisis data dalam penelitian ini yaitu sebagai berikut :

1. Mengumpulkan data melalui pengisian kuesioner oleh responden.

2. Melakukan uji validitas dan reliabilitas kuesioner.

3. Melakukan analisis faktor dengan langkahlangkah sebagai berikut :

a. Menguji variabel indikator yang ditentukan dengan metode Bartlett Test of Sphericity, KMO (Kaiser Mayer Olkin), dan MSA (measure of sampling adequacy).

b. Menentukan ragam dari masing-masing indikator yang terbentuk agar diketahui keeratan hubungannya.

c. Menentukan jumlah faktor berdasarkan masing-masing indikator. Faktor-faktor yang dipilih adalah faktor yang memiliki akar ciri $>1$.

d. Merotasi faktor yaitu untuk mempermudah interpretasi dalam menentukan variabel-variabel yang tercantum dalam faktor.

e. Melakukan interpretasi faktor yang telah ditentukan, dengan menentukan indikator yang termasuk pada masingmasing faktor.

\section{HASIL DAN PEMBAHASAN}

\subsection{Uji Validitas dan Reliabilitas}

Validitas digunakan untuk mengetahui kelayakan daftar pernyataan dalam mendefinisikan suatu variabel. Validitas didefinisikan sebagai sejauh mana ketepatan dan kecermatan suatu alat ukur dalam melakukan fungsi ukurannya (Riduwan, 2004). Reliabilitas adalah indeks yang menunjukkan sejauh mana suatu alat ukur dapat dipercaya. Apabila nilai Alpha Cronbach $\geq 0,60$ maka data dikatakan reliabel. Hal ini berarti alat ukur tersebut dapat digunakan untuk mengukur dua kali atau lebih gejala yang sama dengan alat yang konsisten (Ghozali, 2007).

Pada Tabel 2 dari seluruh variabel terdapat enam variabel yang tidak valid yaitu pada variabel $\mathrm{X}_{5}, \mathrm{X}_{7}, \mathrm{X}_{13}, \mathrm{X}_{16}, \mathrm{X}_{17}, \mathrm{X}_{26}$ karena nilai korelasinya kurang dari 0,3 dengan nilai Cronbach's Alpha total sebesar 0,876. Setelah variabel $\mathrm{X}_{5}, \mathrm{X}_{7}, \mathrm{X}_{13}, \mathrm{X}_{16}, \mathrm{X}_{17}, \mathrm{X}_{26}$ dihilangkan, dilakukan uji validitas dan reliabilitas ulang.

Tabel 2. Uji Validitas dan Reliabilitas

\begin{tabular}{|c|c|c|}
\hline & $\begin{array}{c}\text { Item-Total } \\
\text { Correlation }\end{array}$ & $\begin{array}{c}\text { Cronbach's Alpha } \\
\text { if Item Deleted }\end{array}$ \\
\hline X1 & .575 & .868 \\
\hline X2 & .461 & .871 \\
\hline X3 & .420 & .873 \\
\hline X4 & .436 & .876 \\
\hline X5 & .161 & .878 \\
\hline X6 & .562 & .869 \\
\hline X7 & .167 & .878 \\
\hline X8 & .711 & .864 \\
\hline X9 & .641 & .869 \\
\hline X10 & .601 & .868 \\
\hline X11 & .382 & .874 \\
\hline X12 & .356 & .874 \\
\hline X13 & .209 & .878 \\
\hline X14 & .581 & .868 \\
\hline X15 & .486 & .870 \\
\hline X16 & .225 & .876 \\
\hline X17 & .287 & .876 \\
\hline X18 & .510 & .870 \\
\hline X19 & .410 & .873 \\
\hline X20 & .692 & .864 \\
\hline X21 & .726 & .864 \\
\hline X22 & .674 & .868 \\
\hline X23 & .689 & .866 \\
\hline X24 & .586 & .869 \\
\hline X25 & .646 & .867 \\
\hline X26 &. .362 & .894 \\
\hline & & \\
\hline
\end{tabular}

Tabel 3. Uji Validitas \& Reliabilitas Setelah Variabel $\mathrm{X}_{5}, \mathrm{X}_{7}, \mathrm{X}_{13}, \mathrm{X}_{16}, \mathrm{X}_{17}, \mathrm{X}_{26}$ dihilangkan.

\begin{tabular}{|c|c|c|}
\hline & $\begin{array}{c}\text { Item-Total } \\
\text { Correlation }\end{array}$ & $\begin{array}{c}\text { Cronbach's Alpha } \\
\text { if Item Deleted }\end{array}$ \\
\hline $\mathrm{X} 1$ & .620 & .898 \\
\hline $\mathrm{X} 2$ & .513 & .901 \\
\hline $\mathrm{X} 3$ & .485 & .902 \\
\hline $\mathrm{X} 4$ & .489 & .908 \\
\hline $\mathrm{X} 6$ & .596 & .899 \\
\hline $\mathrm{X} 8$ & .705 & .895 \\
\hline $\mathrm{X} 9$ & .591 & .900 \\
\hline $\mathrm{X} 10$ & .570 & .900 \\
\hline $\mathrm{X} 11$ & .395 & .905 \\
\hline $\mathrm{X} 12$ & .321 & .905 \\
\hline $\mathrm{X} 14$ & .610 & .899 \\
\hline $\mathrm{X} 15$ & .488 & .901 \\
\hline $\mathrm{X} 18$ & .517 & .902 \\
\hline $\mathrm{X} 19$ & .384 & .904 \\
\hline $\mathrm{X} 20$ & .691 & .896 \\
\hline $\mathrm{X} 21$ & .755 & .894 \\
\hline $\mathrm{X} 22$ & .623 & .899 \\
\hline $\mathrm{X} 23$ & .683 & .897 \\
\hline $\mathrm{X} 24$ & .590 & .899 \\
\hline $\mathrm{X} 25$ & .586 & .899 \\
\hline & & \\
\hline
\end{tabular}


Pada Tabel 3 terlihat bahwa seluruh variabel sudah valid karena nilai korelasinya lebih dari 0,3 dan memiliki nilai Cronbach's Alpha sebesar 0,905 yang berarti bahwa Alpha Cronbach $\geq 0,6$ sehingga item-item pernyataan dapat dikatakan reliabel dan kuesioner layak digunakan.

\subsection{Analisis Faktor}

Data penelitian ini diolah menggunakan program SPSS for Windows 23.0. uji kelayakan data digunakan untuk melihat apakah data layak diolah menggunakan analisis faktor. Uji kelayakan data akan ditentukan dengan melihat nilai Bartllett Test of Sphericity, Kaiser Meyer Oikin (KMO), dan Measures of Sampling Adequacy (MSA) yang akan dicari pada masing-masing variabel. Nilai besaran yang harus dipenuhi adalah nilai Bartllett Test of Sphericity dengan significance $<0,05$, nilai KMO harus $\geq 0,5$, dan nilai MSA harus $\geq 0,5$ agar tiap variabel layak untuk dianalisis lebih lanjut (Hair et al, 2010). Nilai KMO yang diperoleh oleh seluruh variabel adalah 0,900 , di mana nilai KMO tersebut sudah memenuhi syarat. Secara umum analisis faktor dapat digunakan pada seluruh variabel yang terbentuk. Untuk nilai signifikansi dalam uji Bartllett di atas menyatakan bahwa nilai 0,000 $<$ 0,05. Maka disimpulkan korelasi antar variabel yang menjadi pembentuk faktor dapat diterangkan oleh variabel lainnya.

Selanjutnya adalah melakukan uji MSA, menurut Johnson \& Wichern (1998) nilai MSA harus $\geq 0,5$. Dalam penelitian ini kriteria MSA yang dipakai adalah $\geq 0,5$.

Tabel 4. Nilai Measures of Sampling Adequacy (MSA)

\begin{tabular}{|c|l|c|}
\hline No & \multicolumn{1}{|c|}{$\begin{array}{c}\text { Indikator-indikator Kualitas } \\
\text { Pelayanan }\end{array}$} & MSA \\
\hline 1 & Area terminal yang luas $\left(X_{1}\right)$ & 0.867 \\
\hline 2 & $\begin{array}{l}\text { Tersedia loket penjualan karcis } \\
\left(X_{2}\right)\end{array}$ & 0.856 \\
\hline 3 & $\begin{array}{l}\text { Ruang tunggu penumpang nyaman } \\
\left(X_{3}\right)\end{array}$ & 0.892 \\
\hline 4 & $\begin{array}{l}\text { Kamar kecil, toilet, MCK tersedia } \\
\text { dan bersih }\left(X_{4}\right)\end{array}$ & 0.895 \\
\hline 5 & $\begin{array}{l}\text { Tersedia tempat penitipan barang } \\
\left(X_{6}\right)\end{array}$ & 0.923 \\
\hline 6 & $\begin{array}{l}\text { Penerangan terminal dimalam hari } \\
\left(X_{8}\right)\end{array}$ & 0.882 \\
\hline 7 & $\begin{array}{l}\text { Waktu menunggu keberangkatan } \\
\text { angkutan umum }\left(X_{9}\right)\end{array}$ & 0.908 \\
\hline
\end{tabular}

Tabel 4. Nilai Measures of Sampling Adequacy (MSA) (Lanjutan)

\begin{tabular}{|c|c|c|}
\hline No & $\begin{array}{c}\text { Indikator-indikator Kualitas } \\
\text { Pelayanan }\end{array}$ & MSA \\
\hline 8 & $\begin{array}{l}\text { Jadwal kedatangan dan } \\
\text { keberangkatan angkutan umum } \\
\text { tepat waktu }\left(X_{10}\right)\end{array}$ & 0.885 \\
\hline 9 & $\begin{array}{l}\text { Tidak ada pemungutan liar seperti } \\
\text { calo }\left(X_{1 l}\right)\end{array}$ & 0.879 \\
\hline 10 & Kebersihan terminal $\left(X_{12}\right)$ & 0.926 \\
\hline 11 & $\begin{array}{l}\text { Tersedia Rambu dan papan } \\
\text { informasi }\left(X_{14}\right)\end{array}$ & 0.905 \\
\hline 12 & $\begin{array}{l}\text { Penindakan tegas petugas bagi } \\
\text { yang melanggar }\left(X_{15}\right)\end{array}$ & 0.937 \\
\hline 13 & $\begin{array}{l}\text { Waktu operasional angkutan umum } \\
24 \text { jam }\left(X_{18}\right)\end{array}$ & 0.883 \\
\hline 14 & $\begin{array}{l}\text { Keramahan petugas terminal dalam } \\
\text { melayani penumpang }\left(X_{19}\right)\end{array}$ & 0.922 \\
\hline 15 & $\begin{array}{l}\text { Kemampuan petugas terminal } \\
\text { mengatur lalulintas angkutan } \\
\text { umum }\left(X_{20}\right)\end{array}$ & 0.884 \\
\hline 16 & $\begin{array}{l}\text { Jaminan keamanan dan } \\
\text { keselematan di area terminal }\left(X_{2 I}\right)\end{array}$ & 0.878 \\
\hline 17 & $\begin{array}{l}\text { Ketegasan petugas terminal dalam } \\
\text { penertiban }\left(X_{22}\right)\end{array}$ & 0.892 \\
\hline 18 & $\begin{array}{l}\text { Perhatian petugas terhadap keluhan } \\
\left(X_{23}\right)\end{array}$ & 0.904 \\
\hline 19 & $\begin{array}{l}\text { Keramahan dan kesopanan petugas } \\
\left(X_{24}\right)\end{array}$ & 0.905 \\
\hline 20 & $\begin{array}{l}\text { Tersedia Fasilitas pengaduan } \\
\text { apabila ada keluhan }\left(X_{25}\right)\end{array}$ & 0.919 \\
\hline
\end{tabular}

Berdasarkan Tabel 4, hasil dari uji MSA menyatakan bahwa setiap indikator memiliki nilai MSA $\geq 0,5$ yang berarti korelasi antar indikator kuat, sehingga memenuhi kriteria dan dapat dipakai untuk analisis lebih lanjut.

\subsection{Penentuan Jumlah Faktor}

Penentuan jumlah faktor ditentukan melalui nilai eigen. Faktor dengan nilai eigen lebih dari 1 merupakan faktor yang akan dipilih, semakin besar nilai eigen pada suatu faktor maka semakin baik faktor tersebut dalam mewakili sejumlah variabel.

Tabel 5. Nilai Eigen

\begin{tabular}{|c|c|c|c|}
\hline \multirow{2}{*}{ Component } & \multicolumn{3}{|c|}{ Initial Eigenvalues } \\
\cline { 2 - 4 } & Total & $\begin{array}{c}\text { \% of } \\
\text { Variance }\end{array}$ & Cumulative \% \\
\hline 1 & 8.653 & 43.266 & 43.266 \\
\hline 2 & 1.492 & 7.458 & 50.275 \\
\hline 3 & 1.215 & 6.075 & 56.800 \\
\hline 4 & 1.146 & 5.730 & 62.530 \\
\hline 5 & 1.056 & 5.278 & 67.807 \\
\hline
\end{tabular}


Dengan menggunakan metode Principal Components Analysis, terdapat lima faktor dengan nilai eigen yang lebih dari satu, dengan persentase kumulatif $67,807 \%$ mampu menjelaskan faktor-faktor kepuasan pengguna terhadap kualitas pelayanan di Terminal Mengwi Badung.

\subsection{Rotasi Faktor}

Analisis faktor dengan ekstraksi Principal Components Analysis diperoleh lima faktor yang memengaruhi kepuasan pengguna terhadap kualitas pelayanan di Terminal Mengwi Badung. Faktor-faktor tersebut memiliki total 20 indikator. Lima faktor baru dalam metode ekstraksi Principal Components Analysis ini masing-masing akan diberi nama baru sesuai dengan pengelompokkan hasil pada rotasi faktor.

\subsection{Interpretasi Faktor}

Interpretasi faktor dilakukan dengan cara mengelompokkan indikator yang memiliki faktor pembobot minimal 0,50 karena sampel yang digunakan pada penelitian ini adalah 120 responden. Variabel yang memiliki faktor pembobot kurang dari 0,50 akan dikeluarkan dari model. Berdasarkan hasil rotasi faktor dapat dilihat pada Tabel 6 bahwa indikatorindikator yang memengaruhi kualitas pelayanan di Terminal Mengwi Badung membentuk lima faktor baru, lima faktor baru dalam penelitian ini masing-masing diberi nama baru sesuai dengan model Servqual.

1. Faktor Kepedulian (Emphaty)

Faktor kepedulian memiliki nilai eigen sebesar 8.653 dan nilai ragam sebesar 43,266\%. faktor ini menjadi faktor utama kepuasan pengguna terhadap kualitas pelayanan di Terminal Mengwi Badung. Faktor ini terbentuk atas tujuh indikator, yaitu:

a. Penindakan tegas petugas bagi yang melanggar $\left(X_{15}\right)$ dengan faktor loading 0,605 ; hal ini berarti bahwa faktor kepedulian petugas untuk menindak tegas bagi yang melanggar memberi nilai kepuasan bagi pengguna terminal Mengwi Badung.

b. Keramahan petugas terminal dalam melayani penumpang $\left(X_{19}\right)$ dengan faktor loading 0,661 ; hal ini berarti bahwa faktor kepedulian disebabkan oleh sikap petugas terminal yang baik dan ramah dalam melayani penumpang.
Tabel 6. Interpretasi Faktor

\begin{tabular}{|c|c|}
\hline \multicolumn{2}{|l|}{ Faktor Kepedulian (Emphaty) } \\
\hline Variabel & Nilai Loading \\
\hline $\begin{array}{l}\text { Jaminan keamanan dan } \\
\text { keselematan }\end{array}$ & 0.544 \\
\hline $\begin{array}{l}\text { Penindakan tegas petugas bagi } \\
\text { yang melanggar }\end{array}$ & 0.605 \\
\hline $\begin{array}{l}\text { Keramahan petugas terminal } \\
\text { dalam melayani penumpang }\end{array}$ & 0.661 \\
\hline $\begin{array}{l}\text { Ketegasan petugas terminal } \\
\text { dalam penertiban }\end{array}$ & 0.677 \\
\hline $\begin{array}{l}\text { Perhatian petugas terhadap } \\
\text { keluhan }\end{array}$ & 0.693 \\
\hline $\begin{array}{l}\text { Tersedia fasilitas pengaduan } \\
\text { apabila ada keluhan }\end{array}$ & 0.782 \\
\hline $\begin{array}{l}\text { Keramahan dan kesopanan } \\
\text { petugas terhadap penumpang }\end{array}$ & 0.804 \\
\hline \multicolumn{2}{|l|}{ Faktor Kondisi Fisik (Tangible) } \\
\hline Variabel & Nilai Loading \\
\hline $\begin{array}{l}\text { Tersedia tempat penitipan } \\
\text { barang }\end{array}$ & 0.525 \\
\hline $\begin{array}{l}\text { Kamar kecil, toilet, MCK } \\
\text { tersedia dan bersih. }\end{array}$ & 0.684 \\
\hline Penerangan dimalam hari & 0.699 \\
\hline Tersedia loket penjualan karcis & 0.746 \\
\hline \multicolumn{2}{|l|}{ Faktor Jaminan (Assurance) } \\
\hline Variabel & Nilai Loading \\
\hline $\begin{array}{l}\text { Waktu operasionl angkutan } \\
\text { umum } 24 \text { jam }\end{array}$ & 0.744 \\
\hline $\begin{array}{l}\text { Kemampuan petugas terminal } \\
\text { mengatur lalulintas angkutan } \\
\text { umum }\end{array}$ & 0.751 \\
\hline \multicolumn{2}{|l|}{ Faktor Kehandalan (Reliability) } \\
\hline Variabel & Nilai Loading \\
\hline Kebersihan terminal & 0.519 \\
\hline $\begin{array}{l}\text { Tersedia rambu dan papan } \\
\text { informasi }\end{array}$ & 0.609 \\
\hline $\begin{array}{l}\text { Ruang tunggu penumpang } \\
\text { nyaman }\end{array}$ & 0.695 \\
\hline Area terminal yang luas & 0.731 \\
\hline \multicolumn{2}{|c|}{ Faktor Tanggung Jawab (Responsivness) } \\
\hline Variabel & Nilai Loading \\
\hline $\begin{array}{l}\text { Waktu menunggu keberangkatan } \\
\text { angkutan umum }\end{array}$ & 0.554 \\
\hline $\begin{array}{l}\text { Jadwal kedatangan dan } \\
\text { keberangkatan angkutan umum } \\
\text { tepat waktu }\end{array}$ & 0.651 \\
\hline $\begin{array}{l}\text { Tidak ada pemungutan liar } \\
\text { seperti calo }\end{array}$ & 0.747 \\
\hline
\end{tabular}

c. Jaminan keamanan dan keselematan di area terminal $\left(X_{21}\right)$ dengan faktor loading sebesar 0,544; hal ini berarti bahwa faktor kepedulian disebabkan oleh adanya jaminan keamanan dan keselematan untuk penumpang. 
d. Ketegasan petugas terminal dalam penertiban $\left(X_{22}\right)$ dengan faktor loading sebesar 0,677 ; hal ini berarti faktor kepedulian disebabkan oleh adanya ketegasan petugas terminal dalam melakukan penertiban di Terminal Mengwi Badung.

e. Perhatian petugas terhadap keluhan $\left(X_{23}\right)$ dengan faktor loading 0,693 ; hal ini berarti bahwa faktor kepedulian disebabkan oleh perhatian petugas terhadap keluhan yang disampaikan oleh penumpang.

f. Keramahan dan kesopanan petugas $\left(X_{24}\right)$ dengan faktor loading sebesar 0,804; hal ini berarti bahwa faktor kepedulian disebabkan oleh keramahan dan kesopanan petugas dalam melayani penumpang di terminal Mengwi Badung.

g. Tersedia fasilitas pengaduan bila ada keluhan $\left(X_{25}\right)$ dengan faktor loading sebesar 0,782; hal ini berarti bahwa faktor kepedulian disebabkan oleh dengan adanya fasilitas pengaduan untuk penumpang apabila terdapat keluhan yang ingin disampaikan.

\section{Faktor Kondisi Fisik (Tangible)}

Faktor Kualitas Pelayanan memiliki nilai eigen sebesar 1,492 dan nilai ragam sebesar $7,458 \%$. Faktor ini terbentuk atas empat indikator yaitu:

a. Tersedia loket penjualan karcis $\left(X_{2}\right)$ dengan faktor loading sebesar 0,746 ; hal ini mengindikasikan bahwa faktor kondisi fisik terminal yang baik ditandai dengan tersedianya loket penjualan karcis untuk penumpang.

b. Kamar kecil, toilet, MCK tersedia dan bersih $\left(X_{4}\right)$ dengan faktor loading sebesar 0,684 ; hal ini mengindikasikan bahwa faktor kondisi fisik terminal yang baik ditandai dengan tersedianya kamar kecil, toilet, maupun MCK yang bersih untuk pengunjung terminal.

c. Tersedia tempat penitipan barang $\left(X_{6}\right)$ dengan faktor loading sebesar 0,525 ; hal ini mengindikasikan bahwa faktor kondisi fisik terminal yang baik ditandai dengan tersedianya tempat penitipan barang bagi penumpang yang mungkin ingin menitipkan barang sementara waktu selama berada di terminal.

d. Penerangan dimalam hari $\left(X_{8}\right)$ dengan faktor loading sebesar 0,699 ; hal ini mengindikasikan bahwa faktor kondisi fisik terminal yang baik ditandai dengan tersedianya lampu penerangan dimalam hari yang dapat memudahlan aktifitas pengunjung terminal.

\section{Faktor Jaminan (Assurance)}

Faktor Jaminan memiliki nilai eigen sebesar 1,215 dan nilai ragam sebesar 6,075\%. Faktor ini terbentuk atas dua variabel yaitu:

a. Waktu operasional angkutan umum 24 jam $\left(X_{18}\right)$ dengan faktor loading sebesar 0,744 ; hal ini mengindikasikan bahwa faktor jaminan (assurance) yang baik ditandai dengan waktu operasional angkutan umum yang 24 jam.

b. Kemampuan petugas terminal mengatur lalulintas angkutan umum $\left(X_{20}\right)$ dengan faktor loading 0,751 ; hal ini mengindikasikan bahwa faktor jaminan (assurance) yang baik ditandai dengan kemampuan petugas terminal mengatur lalulintas angkutan umum.

\section{Faktor Kehandalan (Reliability)}

Faktor Kehandalan memiliki nilai eigen sebesar 1,146 dan nilai ragam sebesar 5,730\%. Faktor ini terbentuk atas empat indikator yaitu:

a. Area terminal yang luas $\left(X_{I}\right)$ dengan faktor loading sebesar 0,731 ; hal ini mengindikasikan bahwa faktor kehandalan ditandai dengan tersedianya area terminal yang luas yang mampu meningkatkan kenyamanan pengunjung terminal.

b. Ruang tunggu penumpang nyaman $\left(X_{3}\right)$ dengan faktor loading sebesar 0,695; hal ini mengindikasikan bahwa faktor kehandalan ditandai dengan tersedianya ruang tunggu penumpang yang mampu meningkatkan kenyaman penumpang ketika menunggu jam keberangkatan angkutan umum.

c. Kebersihan terminal $\left(X_{12}\right)$ dengan faktor loading sebesar 0,519; hal ini mengindikasikan bahwa faktor kehandalan ditandai dengan tingkat kebersihan terminal.

d. Tersedia rambu dan papan informasi $\left(X_{14}\right)$ dengan faktor loading sebesar 0,609 ; hal ini mengindikasikan bahwa faktor kehandalan ditandai dengan tersedianya rambu dan papan informasi yang mampu yang mampu memudahkan penumpang dalam memperoleh infomasi waktu operasional angkutam umum. 
5. Faktor Tanggung Jawab (Responsivness) Faktor Tanggung Jawab memiliki nilai eigen sebesar 1,056 dan nilai ragam sebesar $5,278 \%$. Faktor ini terbentuk atas tiga indikator yaitu:

a. Waktu menunggu keberangkatan angkutan umum $\left(X_{9}\right)$ dengan faktor loading sebesar 0,554 ; hal ini mengindikasikan bahwa faktor tanggung jawab ditandai dengan waktu menunggu keberangkatan angkutan umum sesuai dengan jam operasional yang telah ditetapkan sebelumnya.

b. Jadwal kedatangan dan keberangkatan angkutan umum di terminnal tepat waktu $\left(X_{10}\right)$ dengan faktor loading sebesar 0,651 ; hal ini mengindikasikan bahwa faktor tanggung jawab ditandai dengan jadwalkedatangan dan keberangkatan angkutan umum sesuai dengan jam operasional yang telah ditetapkan sebelumnya.

c. Tidak ada pemungutan liar seperti calo $\left(X_{11}\right)$ dengan faktor loading sebesar 0,757 ; hal ini berarti bahwa faktor tanggung jawab petugas terminal dalam mengawasi adanya pemungutan liar yang dilakukan para calo.

\section{KESIMPULAN DAN SARAN}

\subsection{Kesimpulan}

Berdasarkan hasil analisis dan pembahasan, maka peneliti dapat menyimpulkan bahwa:

1. Faktor-faktor kepuasan pengguna terhadap kualitas pelayanan di terminal Mengwi Badung adalah faktor kepedulian, faktor kondisi fisik, faktor jaminan, faktor kehandalan, dan faktor tanggung jawab. Faktor-faktor tersebut dapat menjelaskan keragaman kepuasan pengguna terhadap kualitas pelayanan di terminal Mengwi Badung sebesar 67,807\%.

2. Faktor dominan yang melatarbelakangi kepuasan pengguna terhadap kualitas pelayanan di terminal Mengwi Badung adalah faktor kepedulian yaitu sebesar $43,266 \%$. Indikator-indikator dalam faktor ini yaitu penindakan tegas petugas bagi yang melanggar dengan faktor pembobot sebesar 0,605 ; sikap petugas terminal dalam melayani penumpang dengan faktor pembobot sebesar 0,661; jaminan keamanan dan keselematan dengan faktor pembobot sebesar 0,544; ketegasan petugas terminal dalam penertiban dengan faktor pembobot sebesar 0,677 ; perhatian petugas terhadap keluhan dengan faktor pembobot sebesar 0,693; keramahan dan kesopanan petugas dengan faktor pembobot sebesar 0,804; dan fasilitas pengaduan bila ada keluhan dengan faktor pembobot sebesar 0,782 .

\subsection{Saran}

Berdasarkan hasil dari penelitian, saran penelitian selanjutnya yaitu untuk menggunakan lebih banyak variabel yang mampu berpengaruh terhadap kepuasan pengguna sehingga lebih dapat meningkatkan kualitas pelayanan.

\section{DAFTAR PUSTAKA}

BPS. (2019, Juli). Jumlah Wisatawan Asing ke Bali Menurut Bulan, 1982-2019. Retrieved from Badan Pusat Statistik Provinsi Bali: https://bali.bps.go.id/statictable/2018/02/09 121/jumlah-wisatawan-asing-ke-balimenurut-bulan-1982-2019.html

Dishubkominfo Badung. (2018). Profil Terminal Mengwi Badung. Retrieved from http://www.dishubkominfo.badungkab.go.i d/sarana-dan-prasarana/

Disparda Bali. (2017). Jumlah Kunjungan Wisatawan Mancanegra. Retrieved April 28, 2016, from http://www.disparda.baliprov.go.id/en/Stati stics2

Ghozali, I. (2007). Aplikasi Analisis Multivariate dengan Program SPSS. Semarang: Badan Penerbit Universitas Diponegoro.

Giri, N. C. (2004). Multivariate Statistical Analysis. New Jersey: Marcel Dekker, Inc.

Jhonson, R. A., \& Wichern, D. W. (1998). Applied Multivariate Statistical Analisis. New Jersey: Pearson International Edition.

Kotler, P. (2000). Marketing Management. New Jersey: Prentice-Hall, Inc.

Lupiyoadi, R. (2006). Manajemen Pemasaran Jasa. Jakarta: Selamba Empat.

Parasuraman, A., Zeithmal, A. V., \& Berry, L. L. (1988). Servequal: A Multiple Item Scale for Measuring Consumer Perceptions 
of Service Quality. Journal of Retailing, 23.

Saputra, M. Y. (2010). Analisa Tingkat Kepuasan Pengguna Jasa Terhadap Kinerja Pelayanan Terminal Makassar Metro Kota Makassar. Tesis. Institut Teknologi Sepuluh Nopember: Surabaya.

Supranto. (2004). Analisis Multivariat Arti dan Interpretasi. Jakarta: PT Rineka Cipta.

Tjiptono, F. (2006). Manajemen Jasa. Yogyakarta: Andi.

Wright, P. H., Ashford, N. J., \& Stammer, R. J. (1997). Transportation Engineering: Planning and Design, 4th Edition. United States: Wiley.

Yamit, Z. (2005). Manajemen Kualitas Produk dan Jasa. Yogyakarta: Ekonisia Kampus Fakultas Ekonomi. 